\title{
Preliminary Study of Liquid Hydrocarbon Biodegradation By Indigineous Bacteria Isolated from Wonocolo Village, Bojonegoro District, East Java Province
}

\author{
Bramono Dwi Kusumo $^{1}$, Wahyu Wilopo*1, and Endah Retnaningrum ${ }^{2}$ \\ ${ }^{1}$ Department of Geological Engineering, Faculty of Engineering, Universitas Gadjah Mada, Jl. Grafika 2 Yogyakarta \\ 55281 \\ ${ }^{2}$ Faculty of Biology, Universitas Gadjah Mada, JL. Teknika Selatan Sekip Utara, Yogyakarta, Indonesia, 55281
}

\begin{abstract}
Aquatic environmental pollution due to petroleum waste can cause disruption to the environment and damaging of flora and fauna. It has been reported that petroleum contaminatin occurs in the Bengawan Solo river, East Java Province. Liquid hydrocarbon waste pollution can be remediate through various processes, one of them is biodegradation. Biodegradation a part of bioremediation, is the process by which organic substances are decomposed by microorganisms into simpler substances such as carbon dioxide, water and ammonia. Bioremediation has minor side effects compare to other methods because it's more effective, efficient, economical and eco-friendly through biological process. This study aims to identify bacteria for liquid hydrocarbon degradation from the rivers in Wonocolo Village, Bojonegoro District and to determine maximum percentage of inoculum to produce the highest efficiency of liquid hydrocarbons degradation. Based on phenotypic characters, the selected bacteria was identified as a genus of Moraxella. Its bacterium with a concentration of $2 \%$ can reduce hydrocarbons to a maximum of $0.67 \%$ per hour at the exponential phase growth.
\end{abstract}

Keywords: Water pollutan · Biodegradation · Moraxella $\cdot$ Wonocolo $\cdot$ East Java.

\section{INTRODUCTION}

Pollution of the aquatic environment due to hydrocarbon waste discharges may cause disturbance to the environment and is a major danger to the flora and fauna present in water. This is because petroleum contains 50 to $95 \%$ of toxic hydrocarbon compounds and in some cases carcinogenic to plants, animals and humans (Varjani et al., 2017). Pollution of liquid hydrocarbon waste has been observed in Bengawan Solo River. Local people said that the crude oil waste come from traditional oil mining in some villages in Kedewan Sub-district, such as Wonocolo, Beji and Hargomulyo villages. In this area there are around 200 traditional oil wells and liquid hydrocarbon waste

\footnotetext{
${ }^{*}$ Corresponding author: W. WiLOpo, Department of Geological Engineering, Universitas Gadjah Mada. Jl. Grafika 2 Yogyakarta 55281. E-mail: wilopo_w@ugm.ac.id
}

flows to Bengawan Solo Riverin Batokan Village, Kasiman Sub-district, Bojonegoro District. PT. Pertamina Aset IV as supervisors does not have any solution to mitigate of water pollution by liquid hydrocarbonin Wonocolo Village, Kedewan Sub-district. The pollution from liquid hydrocarbon waste will have a negative impact to environment such as damage the ecosystem and pollute the ground water. Most of people in this area use groundwater to support their daily life. According to the Head of the Bojonegoro Environmental Service, the pollution will be widen further as the number of illegal oil wells increase from 200 wells to 722 wells. It is necessary to prevent the pollution by improving of liquid hydrocarbon waste management in the upstream area where the wells are located. Bioremediation is one of methods to remediate contaminated river water by liquid hydrocarbon waste. Bioremedi- 
ation is a method of controlling pollution by biological activity of microbes (Leisinger, 1981; Wilopo et al., 2008). The contamination prevention through a biodegradation process that is part of bioremediation and has minor side effects because it's more effective, efficient, economical and eco-friendly than other methods (Azubuike et al., 2016). Enzymes from these microbes are used to clean and neutralize chemical compounds and waste safely (Jednak et al., 2017).

The bacteria used in the study are bacteria found in rivers or from the aquatic environment and classified as hydrocarbonoclastic bacteria (Marzan et al., 2017). Based on this background, in this research will be examined about bioremediation by bacteria which is expected to be efficient in degrading liquid hydrocarbons.

\section{Methods}

Bacterial isolate was used in this experiment come from the river in Wonocolo Village, Kedewan Sub-district, Bojonegoro District, East Java Province. River water sample as bacteria source was collected by selecting liquid hydrocarbons accumulated in calm water with content a biofilm. The collection was carried out at 2 adjacent sample points and given the codes as WCL1 and WCl2. River water samples as starter for WCL1 and WCL2 in glass bottles were inoculated $10 \%$ each in the $250 \mathrm{~mL}$ Erlenmeyer. This Erlenmeyer glass already contained sterile liquid media in the form of $225 \mathrm{~mL}$ of liquid Bushnell Haas Mineral Salt (BHMS). This liquid medium was prepared by in each $1 \mathrm{~L}$ containing $0.2 \mathrm{~g}$ of $\mathrm{MgSO}_{4} \cdot 7 \mathrm{H}_{2} \mathrm{O}$; $0.02 \mathrm{~g} \mathrm{CaCl}_{2}$ is; $1 \mathrm{~g} \mathrm{KH}_{2} \mathrm{PO}_{4} ; 1 \mathrm{~g} \mathrm{~K}_{2} \mathrm{HPO}_{4} ; 1 \mathrm{~g}$ $\mathrm{NH}_{4} \mathrm{NO}_{3} ; 0.05 \mathrm{~g} \mathrm{FeCl}_{3}$; aquadest as much as $1 \mathrm{~L}$ and $0.5 \%$ of liquid hydrocarbons (estimated concentration in the polluted water) and $1 \%$ Tween 80 . Tween 80 is a polyoxyethylene fatty acid ester surfactant and useful as an enhancer of oil solubility in water. This solution helps bacteria to degrade hydrocarbons as a source of metabolism of these bacteria (Madigan et al., 2012).

Isolation of bacteria using culture of bacteria or microorganisms was carried out up to 3 subculture stages at room temperature, it was intended to obtain a pure culture to be used as isolates (Hadioetomo, 1985). Each culture stage is carried out directly 3 times using two $250 \mathrm{~mL}$ Erlenmeyer containing liquid BHMS and added by Tween 80 as much as $1 \%$ and liquid hydrocarbons as much as $0.5 \%$ and added $10 \%$ starter samples of microorganisms in liquid form (mL) put into $250 \mathrm{~mL}$ Erlenmeyer. Total culture is carried out for 3 weeks with each stage of subculture is one week. After 3 weeks, inoculation was transferred into the agar media with 2 repetitions for each subculture in two Erlenmeyers. One $\mathrm{mL}$ of pure culture obtained from the $3^{\text {rd }}$ stage subculture was transferred to solid media in a petri dish in the form of BHMS added by Tween 80 as much as $1 \%$ and liquid hydrocarbons as much as $0.5 \%$ and added to $20 \%$ agar through pour method plate. Before being transferred, dilution was carried out on a test tube containing $10^{-2}$ aquadest until it was not cloudy. After dilution the subculture which has been diluted as much as $10^{-2}$ is transferred to a petri dish containing agar medium (BHMS agar) and waited for a week. If the colony is attached, then use streak method to identify the various microorganism. This method is done by heating the ose to bunsen lamp and attaching to the colony, then transferred to the new BHMS agar by streaking. The results of the streak method will grow after 1 week following the streak from the ose. The next step is take measurements of colonies using the TPC (Total Plate Count) method before inserting the isolate on the tilt agar.

The results of pure culture or isolates that have been grown on BHMS agar were used for biodegradation analysis. Before the biodegradation test, the optimal isolate was selected using the TPC (Total Plate Count) method for 84 hours with 2 repetitions in the petri dish. The results of pure isolates using ose from $3^{\text {rd }}$ subculture has been inoculated to the petri dish via the pour plate method and refined to the petri dish containing agar with the streak method. The microbes grown on the streak method were taken using ose and put into liquid BHMS on $250 \mathrm{~mL}$ Erlenmeyer for each isolate to be compared to growth, after being added to the liquid BHMS medium, the medium containing the microbial isolates were homogenized, after the medium containing the isolate was homogenized and inoculated into BHMS agar in the petri dish using the pour plate method with 
$10^{-4}, 10^{-5}, 10^{-6}$ dilution for each isolate with 2 repetitions and counted as $t-0$. The method was repeated with a interval of 12 hours. The bacteria will grow for 2 days and the results of the pour plate are calculated per colony for each $t$ (time) which will be displayed in the form of a growth curve.

The results of isolates or pure culture in the isolation stage will be tested through biodegradation test to find an efficiency of microorganisms in the degradation of liquid hydrocarbons. The test was carried out for 84 hours based on the results of the selected isolate growth curve. The experiment using 4 scenarios with different inoculums $(2 \%, 5 \%, 10 \%$ inoculum) and $0 \%$ inoculum as a control. Observation parameters consist of TPH (Total Petroleum Hydrocarbon) test using GC (Gas Chromatography), growth of bacteria test using TPC (Total Plate Count) method, volume of liquid hydrocarbon, $\mathrm{pH}$ test using litmus paper and temperature.

\section{Results AND Discussion}

After 3 weeks of incubation through 3 times subculture, the bacterial starter that become be blackened are indicates there are growth of bacteria in the liquid medium and ready to be transferred to agar medium. After 1 week incubation on agar media, WCL1 showed growth but was contaminated by fungi and WCL2 showed more various colonies. Therefore, only pure isolates taken from WCL2 to use for biodegradation test.

Optimal selection of isolates is needed to obtain optimal bacterial isolates to degrade liquid hydrocarbons. The selection uses the TPC (Total Plate Count) method for 144 hours with an observation interval every 12 hours. TPC (Total Plate Count) is done by counting the number of available colonies for each isolate from WCL2 (Isolate 1 with the name DW1 and isolate 2 with the name DW2). These growth observations can be seen in Figure 1. It can be seen that DW2 is faster growth than DW1 following exponential graph. The lifetime of the bacteria in DW2 is also longer than DW1. DW2 shows after 12 hours have equilibrium grouth, however for DW 1 the growth still continue. Constant growth rate $(\mathrm{m})$ of DW2 is greater than DW1 and reach 0.136 , as shown in Table 1 . Based on the result shown that DW2 is the optimal isolate for biodegradation of liquid hydrocarbons.

Table 1: Comparison of specific growth rates between strain of DW1 and DW2.

\begin{tabular}{cccc}
\hline & DW1 & DW2 & Unit \\
\hline N0 & $390 \times 10^{4}$ & $2700 \times 10^{4}$ & $\mathrm{CFU} / \mathrm{mL}$ \\
$\mathrm{N}$ & $1570 \times 10^{4}$ & $1385 \times 10^{4}$ & $\mathrm{CFU} / \mathrm{mL}$ \\
$\mathrm{K}$ & 0.055817 & 0.196591 & \\
$\mu$ & 0.038681 & 0.136237 & \\
\hline $\mathrm{N} 0$ & The bacteria number at $t_{0}$ incubation \\
$\mathrm{N}$ & The bacteria number at $t_{n}$ incubation \\
$\mathrm{K}$ & The growth rate of bacteria \\
$\mu$ & The specific growth rate of bacteria
\end{tabular}

Bacterial identification was carried out by phenotypic identification. Testing of colonies morphology of DW2 was observed by a trinocular microscope with a lens magnification of $100 / 1$ as shown in Figure 2. The bacterial genus was identified as Moraxella according to several phenotypic parameters based on Breed et al. (2012) in Table 2.

Table 2: Phenotypic characters of strain DW1.

\begin{tabular}{clc}
\hline No. & Characters & \multicolumn{1}{c}{ Results } \\
\hline 1. & $\begin{array}{l}\text { Morphology } \\
\text { Colony }\end{array}$ & $\begin{array}{l}\text { Convex elevation, } \\
\text { smooth margin, all round } \\
\text { with white colour } \\
\text { cocobacil, gram (-) }\end{array}$ \\
& & $(+)$ \\
2. & Biochemistry \\
TSIA test & $(+)$ \\
Catalase test & $(+)$ \\
& Oxidase test \\
Indol test & $(-)$ \\
Gelatin test & $(+)$ \\
Simmon & $(+)$ \\
Citrate test & \\
Identification result & Moraxella \\
\hline
\end{tabular}

Biodegradation test results includes TPH (Total Petroleum Hydrocarbon), hydocarbon volume, $\mathrm{pH}$ and temperature were summarized in Table 3. All samples with contains inoculum have capability to degrade liquid hydrocarbons. However, $2 \%$ inoculum is the best result for degradation process. Figure 3 shows a decrease in the TPH value of in the $2 \%$ inoculum occurs during the exponial phase where the bacteria growth at $t-36$ to $t-48$. Moraxella able to 


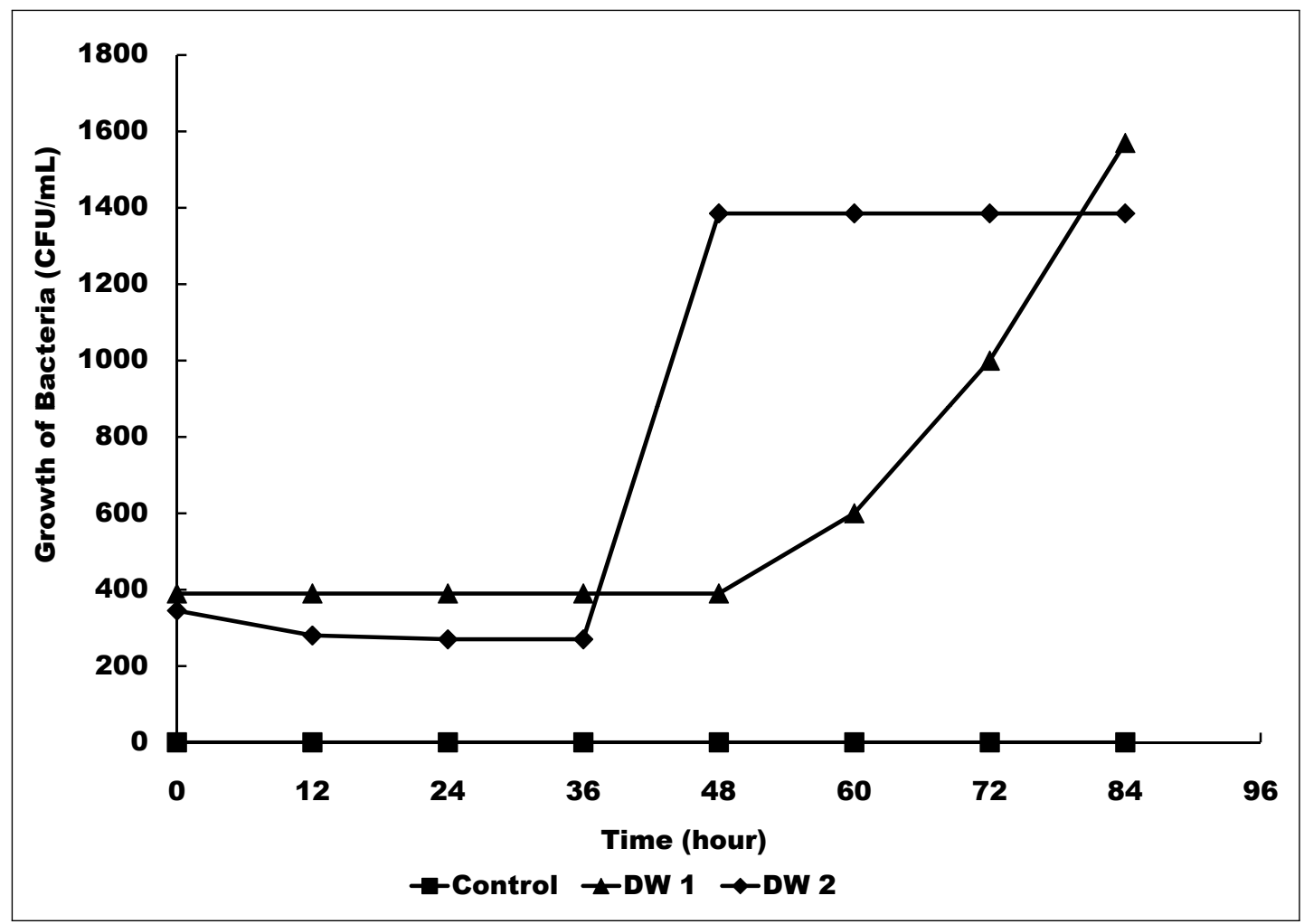

Figure 1: The growth of strain DW1 and DW2 in the BHMS medium added 0.5\% liquid medium at 84 hours incubation.

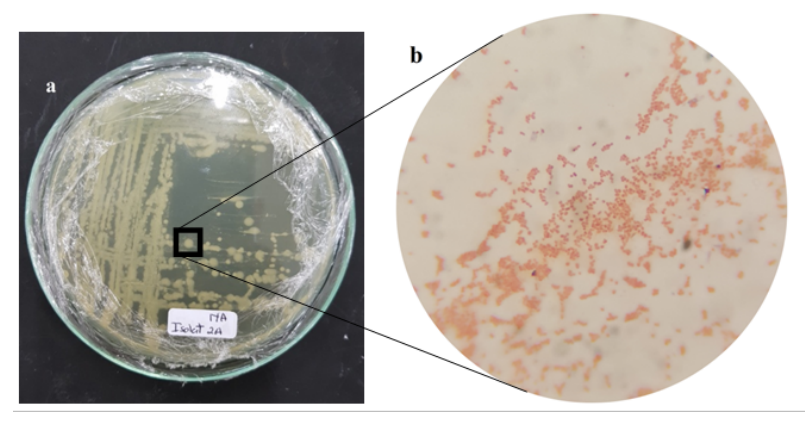

Figure 2: Phenotypic identification: (a) Colony morphology; (b) Cell morphology using a Binocular Microscope with lens magnification of $100 / 1.25$.

degrade hydrocarbon with the rate is $0.67 \%$ per hour in the exponential phase shown in Figure 3 . The volume of liquid hydrocarbon also decreases during experiment, especially in the $2 \%$ inoculum that reach the highest value is $32 \%$ from initial volume (Figure 4). Most of liquid hydrocarbon will be degraded by Moraxella bacteria become water and carbon dioxide (Leahy and Colwell, 1990). During experiment showed Eh value of anaerobic conditions decrease until negative value which means reductive condition due to degradation of liquid hydrocarbon by bacteria. $\mathrm{pH}$ of liqud almost did not change during experiment around 6 to 6.5 . This $\mathrm{pH}$ support for bacteria grow because close to netral conditions. In addition, the temperatur also did not have a big variation during the experiment.

\section{CONCLUSIONS}

Based on phenotypic characters, bacteria isolated from oil polluted rivers in Wonocolo Village was identified as Moraxella. After 4 days incubation, its Moraxella at the $2 \%$ number could reduce the amount of $\mathrm{TPH}$ in liquid hydrocarbons at values of $0.5-0.17 \%$. Its bacteria could also reduce the volume of liquid hydrocarbons of $32 \%$.

\section{ACKNOWLEDGEMENTS}

The authors thank to all members of Microbiology Laboratories in Universitas Gadjah Mada, LPPT Universitas Gadjah Mada for supporting this researach. The authors alaso thanks to Departement of Geological Engineering, Universitas Gadjah Mada for giving a funding to this research.

\section{REFERENCES}


Table 3: Biodegradation test results from DW2.

\begin{tabular}{ccccccc}
\hline & $t$ (hour) & $\mathrm{TPH}(\%)$ & $\begin{array}{c}\text { Liquid HC } \\
\text { Volume } \\
(\mathrm{mL} / 100 \mathrm{~mL})\end{array}$ & $\mathrm{pH}$ & Eh $(\mathrm{mV})$ & $\mathrm{T}\left({ }^{\circ} \mathrm{C}\right)$ \\
\hline \multirow{2}{*}{$0 \%$} & 0 & 0.5 & 0.5 & 6.5 & 87 & 28.0 \\
& 48 & 0.5 & 0.5 & 6.5 & 85 & 28.0 \\
& 84 & 0.5 & 0.5 & 6.4 & 86 & 28.0 \\
\hline \multirow{2}{*}{$2 \%$} & 0 & 0.17 & 0.43 & 6.5 & 66 & 28.0 \\
& 48 & 0.13 & 0.35 & 6.0 & 56 & 29.0 \\
& 84 & 0.17 & 0.34 & 6.0 & 32 & 28.9 \\
\hline \multirow{2}{*}{$5 \%$} & 0 & 0.15 & 0.41 & 6.5 & 38 & 28.0 \\
& 48 & 0.13 & 0.39 & 6.0 & -32 & 28.9 \\
& 84 & 0.19 & 0.395 & 6.0 & -85 & 29.0 \\
\hline \multirow{2}{*}{$10 \%$} & 0 & 0.14 & 0.40 & 6.5 & 28 & 28.0 \\
& 48 & 0.14 & 0.40 & 6.0 & -85 & 28.8 \\
& 84 & 0.18 & 0.35 & 6.0 & -125 & 29.0 \\
\hline
\end{tabular}

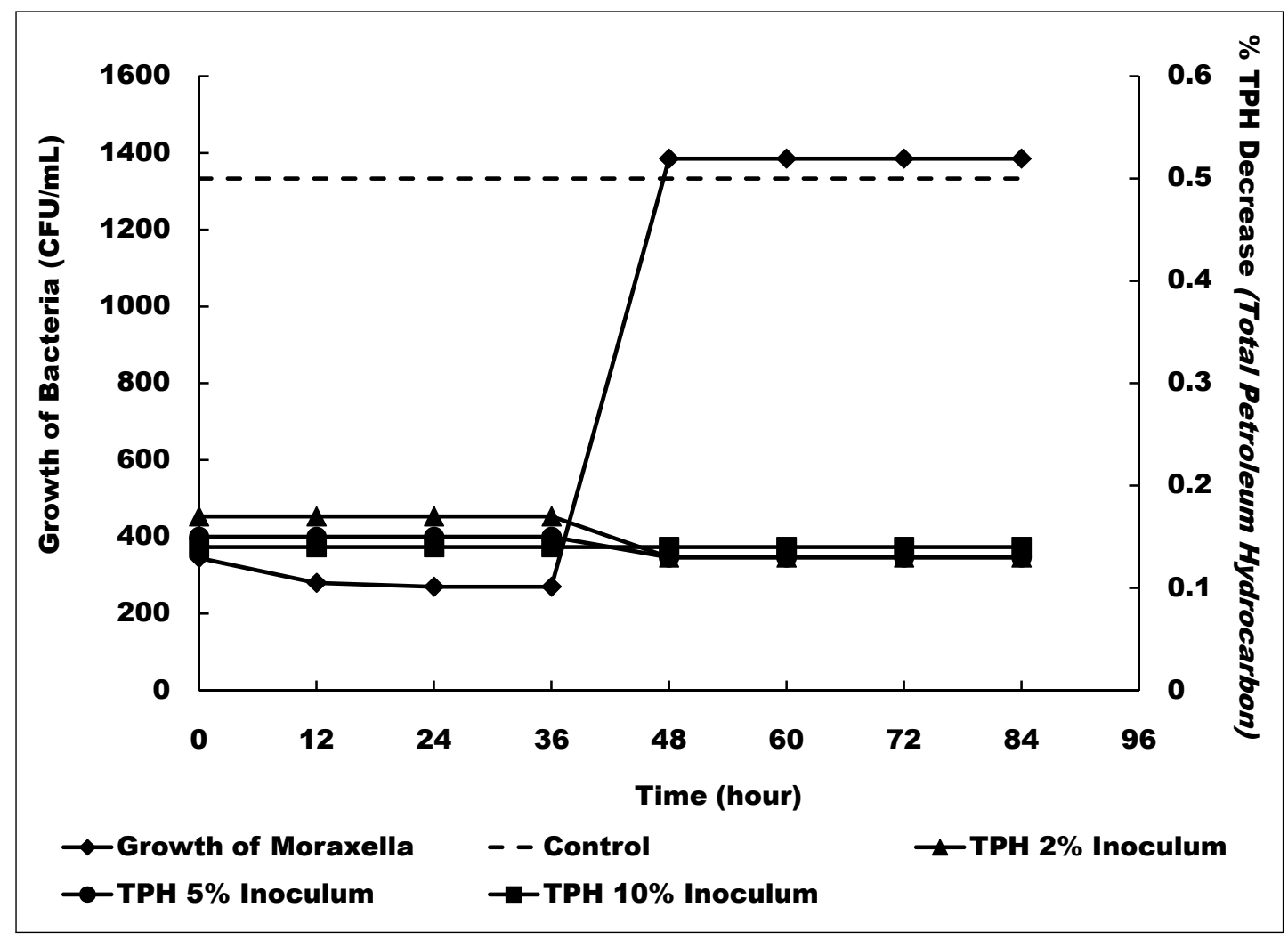

Figure 3: The correlation between bacterial growth and total petroleum hydrocarbon values in a medium at 96 hours incubation. 


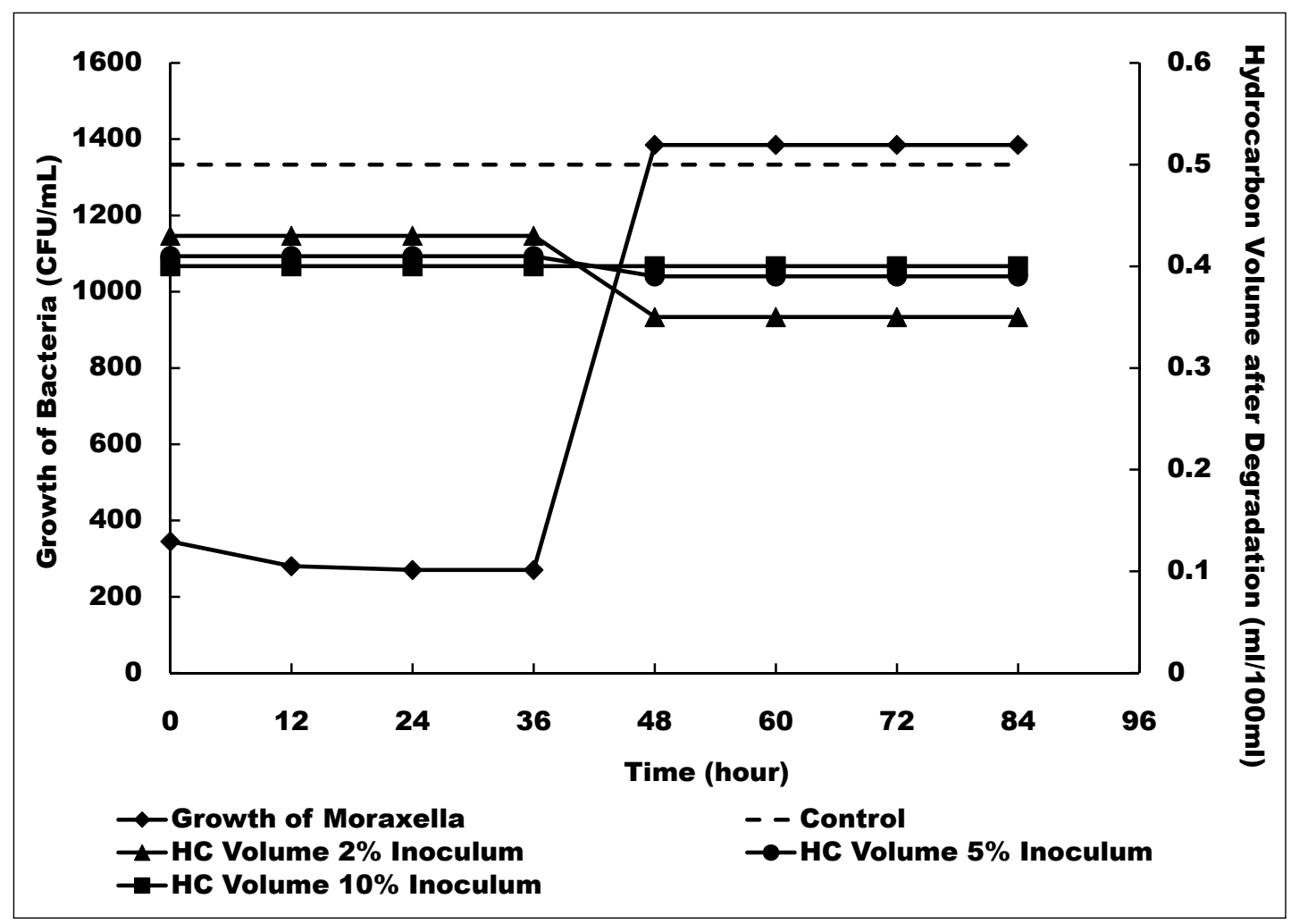

Figure 4: The correlation between bacterial growth and volume of liquid hydrocarbon in a medium at 96 hours incubation.

Breed, R. S., Murray, E. G. D., and Smith, N. R. (1957) Bergey's Manual of Determinative Bacteriology, Seventh Edition, United States of America, The Williams and Wilkins Company.

Hadioetomo, R. S. (1985) Basic Microbiology in Practice of Basic Laboratory Techniques and Procedures, Jakarta, PT Gramedia.

Jednak, T., Avdalovic, J., Milatic, S., Beskoski, L. S., Stankovic, D., Milic, J., Ilic, M., Beskoski, V., Cvijovic, G. G., and Vrvic, M. M. (2017) Transformation and synthesis of humic substances during bioremediation of petroleum hydrocarbons,International Biodeterioration and Biodegradation, Vol. 122, pp. 47-52.

Leahy, J.G., Colwell, R.R. (1990) Microbial Degradation of Hydrocarbon in the Environments, Microbiological Reviews, Vol. 54:3.

Leisinger, T. (1981) Microbial Degradation of Xenobiotic and Recalsitrant Coumpound, London, Academici Press.

Madigan, M. T., Martinko, J. M., Bender, K. S., Buckley, D. H., and Stahl, D. A. (2012) BrockBiology of Microorganisms, $13^{\text {th }}$ Edition, San Fransisco, Benjamin Cummings.
Marzan, L. W., Sultana, T., Hasan, Md. M., Mina, S. A., Islam, Md. R., Rakibuzzaman, A. G. M., Khan, Md. I. H. (2017) Characteization of furnace oil bioremediation potential of hydrocarbonoclastic bacteria isolated from petroleum contaminated sites of the Sundarbans, Bangladesh, Journal of Genetic Engineering and Biotechnology, Vol.15, pp. 103-113.

Azubuike, C.C, Blaise Chikere, C.B., and Okpokwasili, G.C. (2016) Bioremediation techniques-classification based on site of application: principles, advantages, limitations and prospects, World J MicrobiolBiotechnol, Vol. 32:180, 18p.

Varjani, S. J., and Upasani, V. N., 2017,Anew look on factors affecting microbial degradation of petroleum hydrocarbon pollutants, International Biodeterioration and Biodegradation, Vol.120, pp.71-83.

Wilopo, W., Sasaki, K., Hirajima, T., Yamanaka, T. (2008) Immobilization of arsenic and manganese in contaminated groundwater by permeable reactive barriers using zero valent iron and sheep manure, Materials transactions, Vol. 49:10, pp. 22652274 . 